\title{
Identifying Architect Role in Heritage Preservation Processes Using Digital Technology
}

\author{
Mahmoud Foud Mahmoud*, Ahmed Saleh Khedr"*, Fayrouz Ashraf ${ }^{* *}$ \\ * professor at Department of architecture, design, and urban planning, Suez Canal University, Ismailia, Egypt \\ ** professor at Department of architecture, design, and urban planning, Suez Canal University, Ismailia, Egypt \\ **Demonstrator in Architecture Department, Suez Canal University, Ismailia, Egypt \\ DOI: 10.29322/IJSRP.11.10.2021.p11825 \\ http://dx.doi.org/10.29322/IJSRP.11.10.2021.p11825
}

\begin{abstract}
Cities all around the country are growing and changing as they reach new heights and adopt new appearances. Engineering and architecture have progressed in ways that were inconceivable just a few decades ago. However, as these places develop, it becomes increasingly important to preserve structures with history, character, and meaning.

"Adaptive reuse projects preserve distinctive and authentic features that are impossible to replicate in new construction," says the author "Brian Hutt, director of Cushman and Wakefield's Denver office, agreed. "Successful adaptive reuse development combines modern technology with old structures, resulting in an ambiance and sense of place that is impossible to duplicate."

This research discusses the adaptive reuse design process and the need for updating the methods the architects use during its design process, as each historical building has its own design character and architecture identity that should be preserved, so its architecture and significant character is not erased and forgotten.

This research aims to integrate Virtual Reality technologies in adaptive reuse design process of historical buildings, first the theoretical approach is used to describe the literature review about adaptive reuse requirements of historical buildings and Extended reality technologies, the analytical approach is used to analyzing international and national case studies to conclude how VR Technologies could be integrated. The conclusion of this research will be guidelines on how to integrate VR technologies in design process of historical buildings adaptive reuse.
\end{abstract}

Index Terms- Adaptive Reuse - Historical Buildings - Preservation of Heritage - Virtual Reality - Digital Technology - Design Process

\section{INTRODUCTION}

A $\mathrm{s}$ the world as a whole ages, more and more historic structures are in need of rehabilitation; adaptive reuse is the deliberate decision to preserve the past while planning for the future. Adaptive reuse is also known as property rehabilitation or historic redevelopment, depending on the context. In each case, the procedure and final goal are the same: to save abandoned, run-down structures from demolition and give them new life.

Adaptive reuse, on the other hand, isn't only a sentimental endeavor to save buildings; it's also an essential process to ensure that communities don't consume (or waste) more materials than they need. (Korumaz, 2017)

Unfortunately, some communities have chosen to adopt a "newer is better" mentality, prompting them to throw away perfectly good, useable resources in order to "improve." This way of thinking has cased major issues on the environment, and it will continue to do so until we can recognize the value of materials as they age.
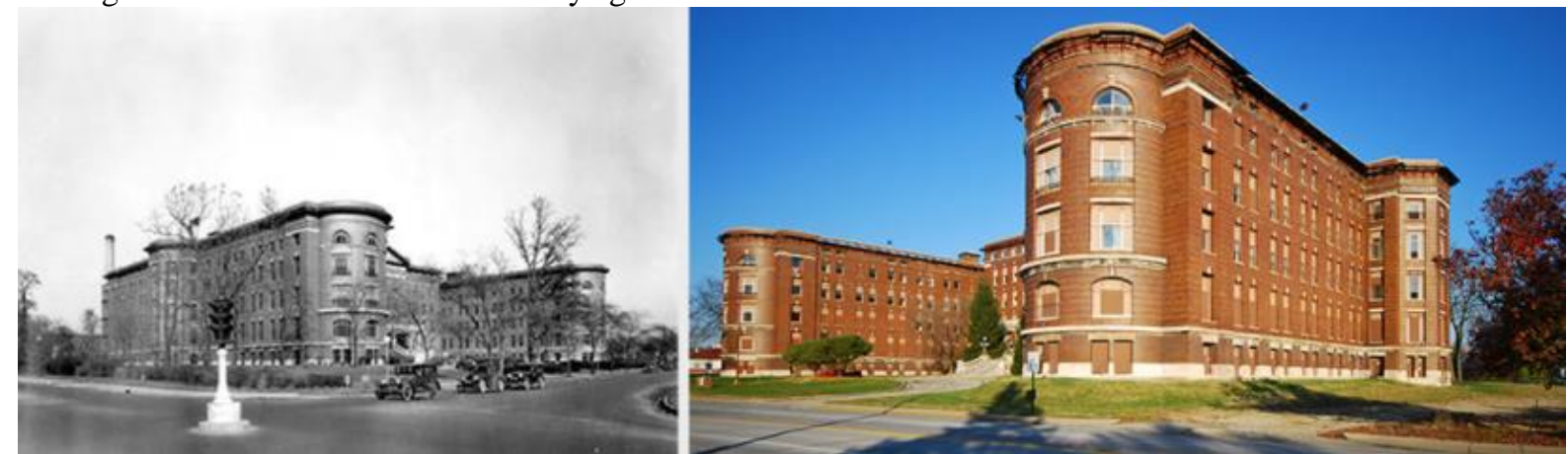

Figure 1 Before: old St. Vincent Hospital, After: IIIInois Fall Creek Center: Ivy Tech Community Collage, Source: https://schmidtarch.com/why-adaptive-reuse-important-todays-world/, accessed: 01/07/2021, 13:42PM 


\section{INTRODUCTION OF ADAPTIVE REUSE}

Adaptive reuse: is a technique for transforming a discarded or inefficient object into a new one that may be utilized for a different purpose. Nothing but the item's use changes from time to time. The adaptive reuse of a historic structure should have a minimal influence on the building's and its heritage significance. Developers should learn why the building is designated as historic, and then explore development that is sensitive to the structure to give it a new use. If the building's heritage values are not protected, adaptive reuse is futile. (Damla Misirlisova, 2016)

\section{A. Adaptive reuse process in historical building}

Any adaptive reuse method is a multidisciplinary process that involves multiple specialists communicating with one another. The model below outlines the processes that must be followed during the decision-making process for adaptive reuse of historic structures. It can be used to describe any type of historic structure that has been abandoned, repurposed, or is no longer in use. In this study, the phrase "heritage building" refers to architectural heritage that has certain heritage qualities, such as industrial heritage buildings or an architectural heritage from the Modernism period. (Damla Misirlisova, 2016)

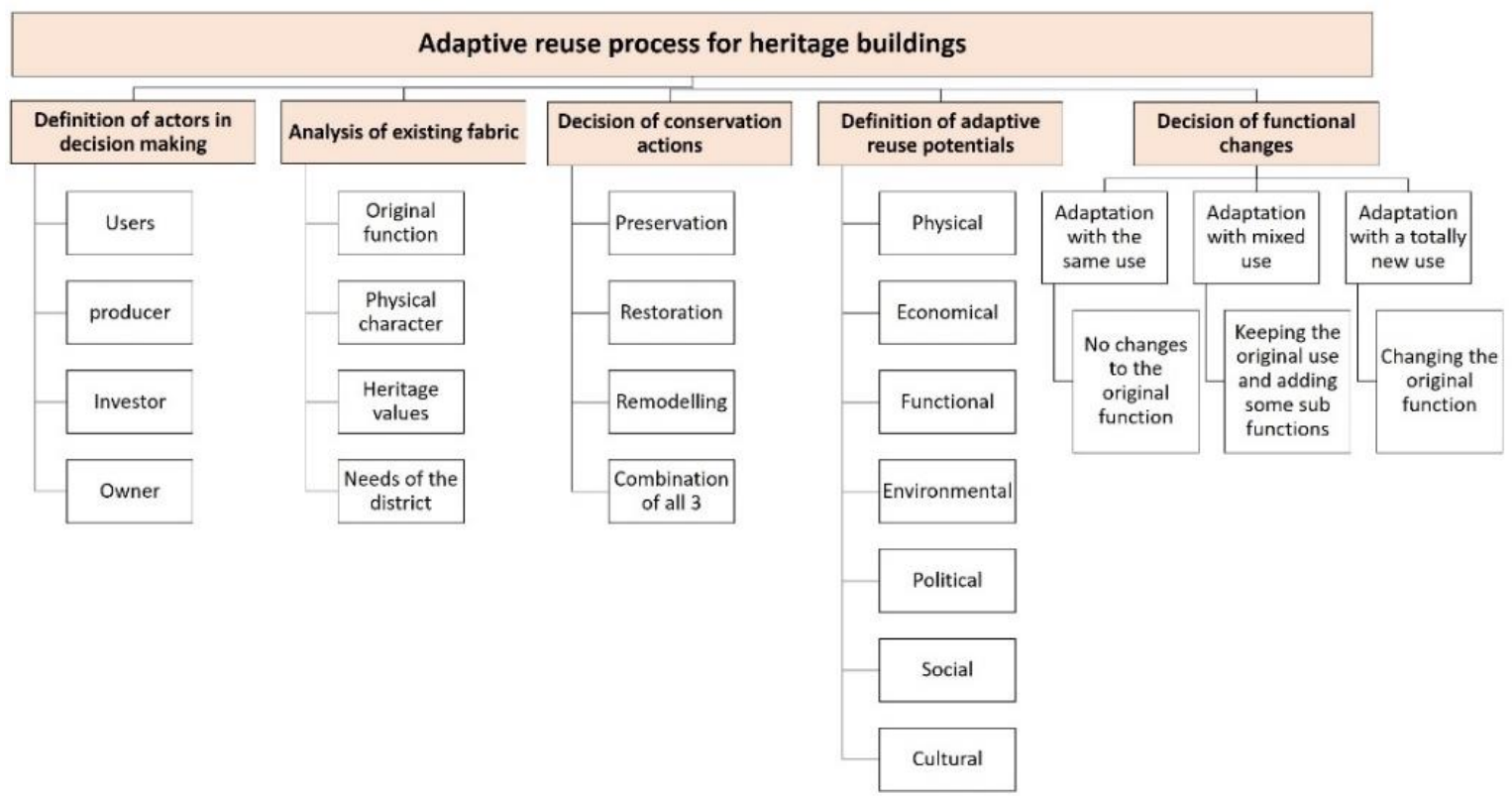

Figure 2 Adaptive Reuse Process in heritage buildings, researcher 22/06/2021, 14:26PM, based on:, Misırlısoy D, Günçe K (2016) Adaptive reuse strategies for heritage buildings: a holistic approach. Sustain Cities Soc 26:91-98 Opportunity. Buildings. 9. 211. 10.3390/buildings9100211.

\section{B. Adaptive reuse requirements}

There are several adaptive reuse requirements that should be adapted and checked for a successful adaptive reuse project; the requirements were analysed and concluded after reviewing several previous studies on adaptive reuse of historical structures; the list of concluded requirements will

Figure 3 The Viability of Adaptive Reuse of Historic Buildings as Schools in Egypt, researcher based on Nermin M. Farrag, Architecture, Civil \& Architectural Engineering Department, Engineering Research Division, National Research Centre, Curr. Sci. Int., 7(3): 337-343, 2018, ISSN: 2077-4435

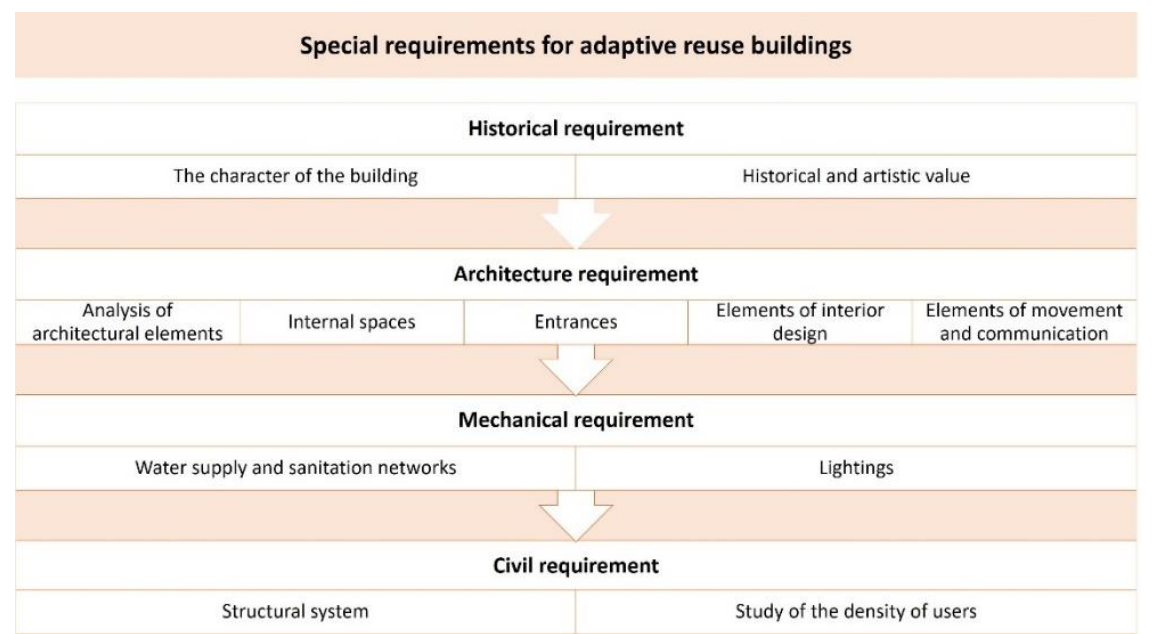


be used in the analysis of international and national adaptive reuse projects. (Farrag, 2018)

\section{Architect Role in Adaptive Reuse Design Process}

The adaptable reused architecture design method is quite different from traditional design approaches, and it may necessitate the employment of other or additional expertise.

When developing a new building, the architect employs an architectural approach that creates the project's order, whether deliberately or unconsciously. Of course, a complicated combination of numerous aspects such as site conditions, structural systems, planning requirements, and his or her own personal vision are augmented by these strategic actions. (Gewirtzman, 2016)

\section{VIRTUAL REALITY, INTRODUCTION, TYPES AND APPLICATIONS}

Virtual reality (VR) is an experience that takes place in simulated and immersive worlds that can be either similar to or very distinct from the actual world. Virtual reality can be used for both amusement (gaming) and educational purposes (i.e. medical or military training). Augmented reality and mixed reality are two other sorts of VR-style technology. (Onvesolu \& Eze, 2011)

Virtual Reality is the technology that is going to be used in this research to aid the architect in historical building adaptive reuse design process.

\section{A. Integration of virtual reality in architecture design process}

It is critical in design to make decisions based on the formation of design hypotheses. These assumptions can be thought of as predictions, which can be influenced by the quality and redundancy of the VR stimulation. The effect of virtual reality on visual perception is highly dependent on the features of these stimulation. Combining various stimulation resulting from the perception of a particular information is referred to as redundancy. The quality of stimuli provided by VR is due to having a realistic representation. For the manipulation of design assumptions, the properties of this representation produce better quality stimuli than drawing. (Dorta \& Lalande, n.d.)

\section{ANAlysis OF SElECTED CASE StUdiES}

In this research 12 international and national Adaptive reuse Projects were analyzed to conclude where the process needs aiding and what is the suitable technology that can aid the architects in the design process.

\section{A. Criteria of Selecting adaptive reuse case studies}

The adaptively reused case studies were selecting according to the following criteria:

- The project has the correct structure of professionals

working on the adaptive reuse that should at least contain Architects

and Archaeologists.

- The case study building should be recognized as a historical building with significant value.

- $\quad$ The adaptive reuse of the historical building changes the function of the original building.

- The adaptive reuse project on the historical building should be already constructed.

- The Varity in choosing case studies in different locations to study and analyze how the architects works on adaptive reuse projects around the world.

B. Analysis of International / National Adaptive Reuse Projects

\begin{tabular}{|c|c|c|c|c|c|c|c|c|}
\hline $\begin{array}{c}\text { Project } \\
\text { Name }\end{array}$ & & Architect & Owner & Type & Style & $\begin{array}{c}\text { Adaptive } \\
\text { Reuse }\end{array}$ & 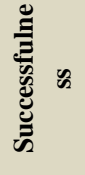 & Figure \\
\hline
\end{tabular}




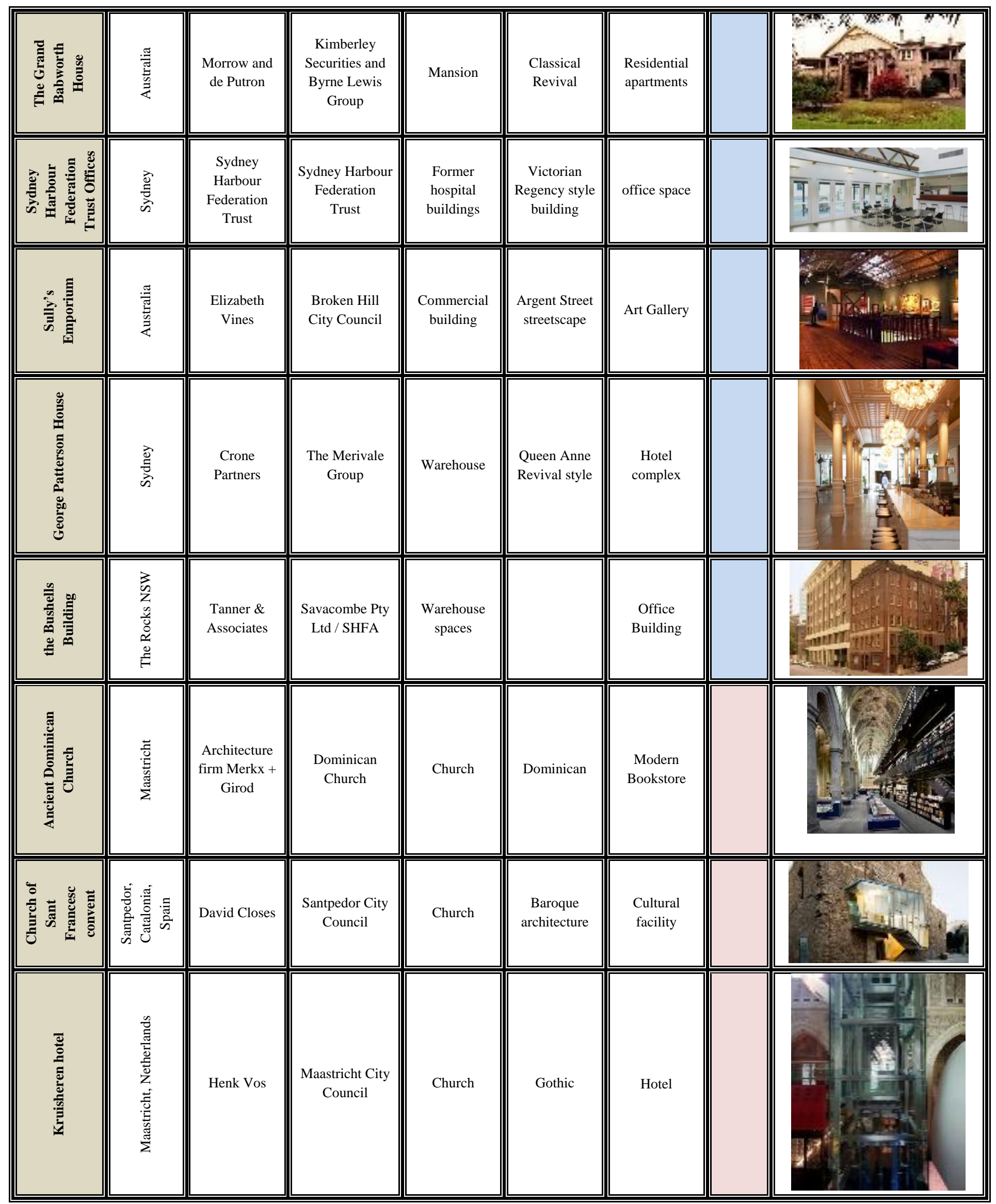




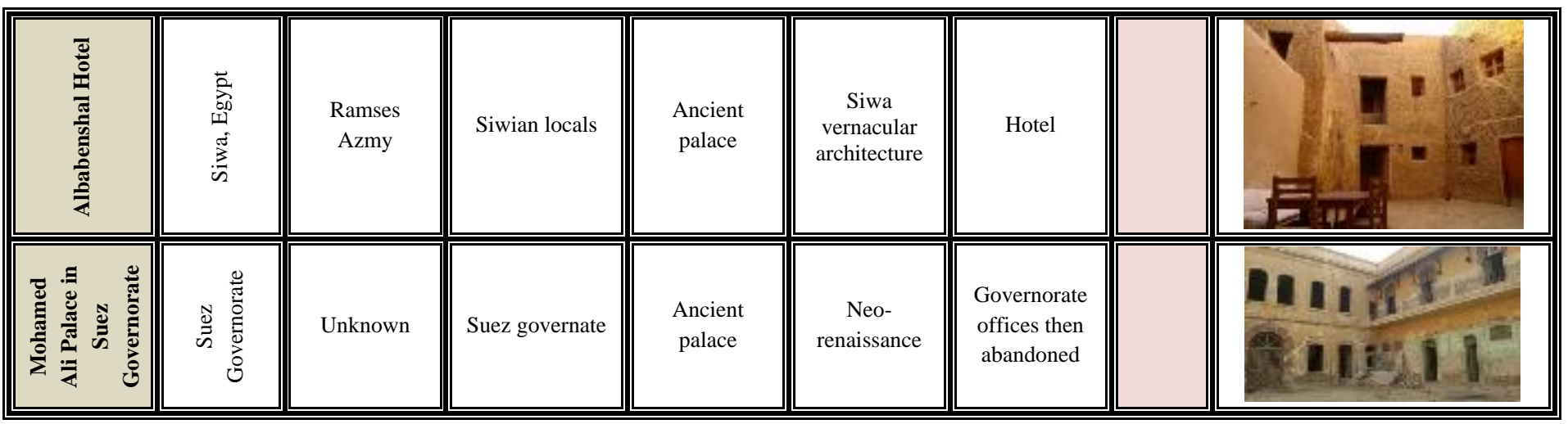

Table 1 Analysis of international and national Adaptive reuse Projects, source: Researcher, 01/07/2021, 14:38PM

Following is a table that summarize the requirements of adaptive reuse and how the architect should successfully design, also where the unsuccessful adaptive reuse project neglected the requirements so that the tool that will aid the architect in adaptive reuse design could be integrated.

\begin{tabular}{|c|c|c|}
\hline $\begin{array}{l}\text { Adaptive Reuse } \\
\text { Requirements }\end{array}$ & $\begin{array}{c}\text { How Architectural design of adaptive reuse } \\
\text { should be to meet requirements (Concluded } \\
\text { from Experiments + Adaptive Reuse } \\
\text { Principles) }\end{array}$ & $\begin{array}{l}\text { How the unsuccessful adaptive reuse projects } \\
\text { neglected adaptive reuse requirements }\end{array}$ \\
\hline $\begin{array}{l}\text { The character of } \\
\text { the building }\end{array}$ & Reveal and interpret the heritage significance & $\begin{array}{c}\text { The survival of architectural integrity has been } \\
\text { significantly affected }\end{array}$ \\
\hline $\begin{array}{l}\text { Historical and } \\
\text { artistic value }\end{array}$ & Ensuring Reversibility of Changes & \\
\hline $\begin{array}{l}\text { Analysis of } \\
\text { architectural } \\
\text { elements }\end{array}$ & $\begin{array}{l}\text { Discouraging the Use of Architectural Salvage } \\
\text { from other Buildings }\end{array}$ & $\begin{array}{c}\text { The architectural elements of the interior were altered } \\
\text { an added on to reach required goal }\end{array}$ \\
\hline Building Exterior & Conserve the Exterior of the Building & $\begin{array}{l}\text { The facade was mostly conserved but affected by for } \\
\text { example metal vertical connecting structures }\end{array}$ \\
\hline Internal spaces & Supporting the Least Intervention & $\begin{array}{l}\text { the existing building's own space, no longer } \\
\text { recognisable and reduced to a mere container }\end{array}$ \\
\hline Entrances & $\begin{array}{c}\text { Conserving the relationship between the setting } \\
\text { and preserve considerable views to and from the } \\
\text { historical place }\end{array}$ & $\begin{array}{l}\text { Some projects altered the by covering it in a modern } \\
\text { double glazed curtain wall with metallic ribs going } \\
\text { through it }\end{array}$ \\
\hline $\begin{array}{c}\text { Elements of interior } \\
\text { design }\end{array}$ & $\begin{array}{l}\text { Preparing the specifications brochure and the } \\
\text { interior and exterior finishes works based on the } \\
\text { decisions of experts in the field of restoration } \\
\text { according to the nature of the building }\end{array}$ & $\begin{array}{l}\text { the link between the ancient architecture and the new } \\
\text { structure is effectively absent }\end{array}$ \\
\hline Lightings & $\begin{array}{c}\text { Understanding the concept of lighting in the } \\
\text { historical building and keeping the alternation to a } \\
\text { minimum }\end{array}$ & Common lighting systems were added to the building \\
\hline $\begin{array}{c}\text { Elements of } \\
\text { movement and } \\
\text { communication }\end{array}$ & $\begin{array}{c}\text { Monitor the connection between the setting and } \\
\text { save critical perspectives to \& from the heritage } \\
\text { place }\end{array}$ & $\begin{array}{l}\text { The linear arrangement and direct circulation of the } \\
\text { space are lost through the perpendicular book stack } \\
\text { installation, which disorientates the visitor }\end{array}$ \\
\hline
\end{tabular}




\begin{tabular}{||c||c||c||}
\hline \hline Structural system & $\begin{array}{c}\text { Analysing and understanding the significance of } \\
\text { the structure as an essential and expressive part of } \\
\text { the adaptation project }\end{array}$ & $\begin{array}{c}\text { The main structure and skin of most buildings was } \\
\text { respected but some interventions and newly added } \\
\text { structures was added to the exterior façade of the } \\
\text { building }\end{array}$ \\
\hline \hline $\begin{array}{c}\text { Social and cultural } \\
\text { data }\end{array}$ & $\begin{array}{c}\text { Understand the significance of the place } \\
\text { data }\end{array}$ & $\begin{array}{c}\text { Providing for the long-range management and } \\
\text { viability of the historical structure }\end{array}$ \\
\hline \hline $\begin{array}{c}\text { Socio economic } \\
\text { data }\end{array}$
\end{tabular}

Table 2 The requirements of adaptive reuse concluded from projects analysis, source: researcher

It was concluded that virtual reality can be integrated in adaptive reuse design process as it can aid the architects in understanding more about the historical character and value of building and how they can incorporate modern material and technology in the new design while respecting the requirements of historical building adaptive reuse and without erasing the significant character of the building.

\begin{tabular}{|c|c|c|c|c|}
\hline \multicolumn{4}{|c|}{ Analysed factor } & $\begin{array}{c}\text { VR Potential in design process } \\
\end{array}$ \\
\hline \multirow{10}{*}{$\begin{array}{l}\text { Preserving the } \\
\text { building's type } \\
\text { and identity }\end{array}$} & \multirow{10}{*}{ 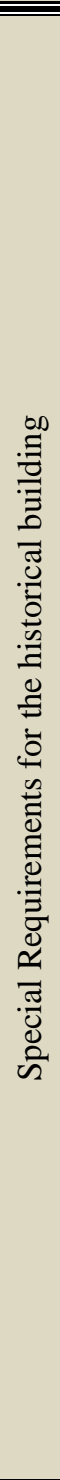 } & \multirow{2}{*}{ 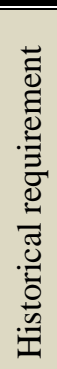 } & $\begin{array}{c}\text { The character of the } \\
\text { building }\end{array}$ & $\begin{array}{l}\text { Beneficial in reviewing the visual components of building elements (Lee, } \\
\qquad 2020)\end{array}$ \\
\hline & & & $\begin{array}{l}\text { Historical and } \\
\text { artistic value }\end{array}$ & $\begin{array}{l}\text { The application of innovative technology in educational practice affects } \\
\text { both the quality and quantity of the content, which is learnt, and } \\
\text { especially how the knowledge is obtained, and which competences the } \\
\text { students develop (Frontera, 2020) }\end{array}$ \\
\hline & & \multirow{7}{*}{ 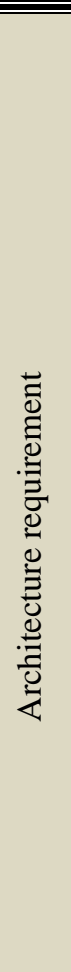 } & $\begin{array}{c}\text { Analysis of } \\
\text { architectural } \\
\text { elements }\end{array}$ & $\begin{array}{c}\text { When using the immersive environment users have a better spatial } \\
\text { perception of the virtual space as opposed to their spatial perception } \\
\text { using a conventional workstation (Paesa, et al., 2017) }\end{array}$ \\
\hline & & & Building Exterior & offered the designer a better perception of space (Campbell, 2021) \\
\hline & & & Internal spaces & VR is already a useful tool in the design process (Campbell, 2021) \\
\hline & & & Entrances & VR is already a useful tool in the design process (Campbell, 2021) \\
\hline & & & $\begin{array}{c}\text { Elements of interior } \\
\text { design }\end{array}$ & $\begin{array}{l}\text { The greater accuracy in identifying certain spatial aspects and distances } \\
\text { using the immersive platform implies a better understanding of the } \\
\text { spatial arrangement of the 3D model. (Paesa, et al., 2017) }\end{array}$ \\
\hline & & & Lightings & $\begin{array}{l}\text { reviewing the visual components of building elements, including colour, } \\
\text { texture, and fenestration. (Lee, 2020) }\end{array}$ \\
\hline & & & $\begin{array}{l}\text { Elements of } \\
\text { movement and } \\
\text { communication }\end{array}$ & students' ability to comprehend an object (Dorta \& Lalande, n.d.) \\
\hline & & & & \\
\hline
\end{tabular}




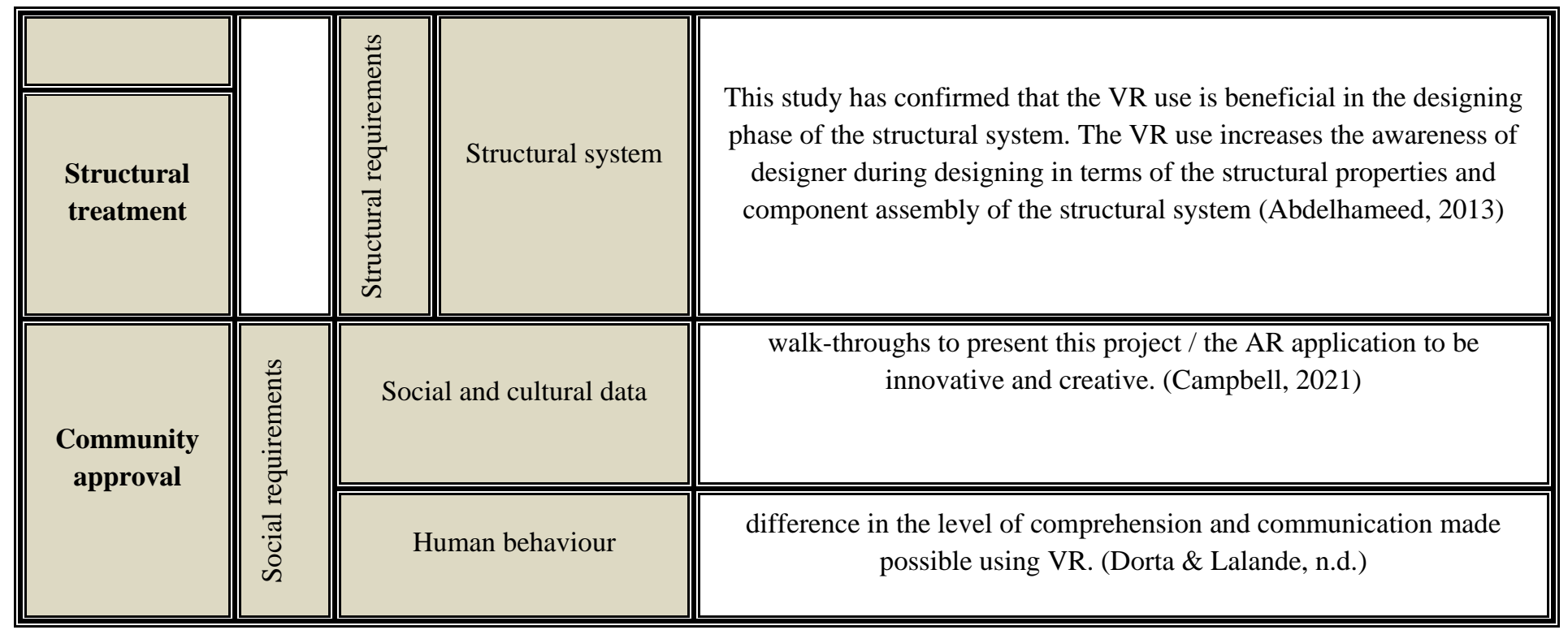

Table 3 Integration of virtual reality in adaptive reuse design process, source: researcher

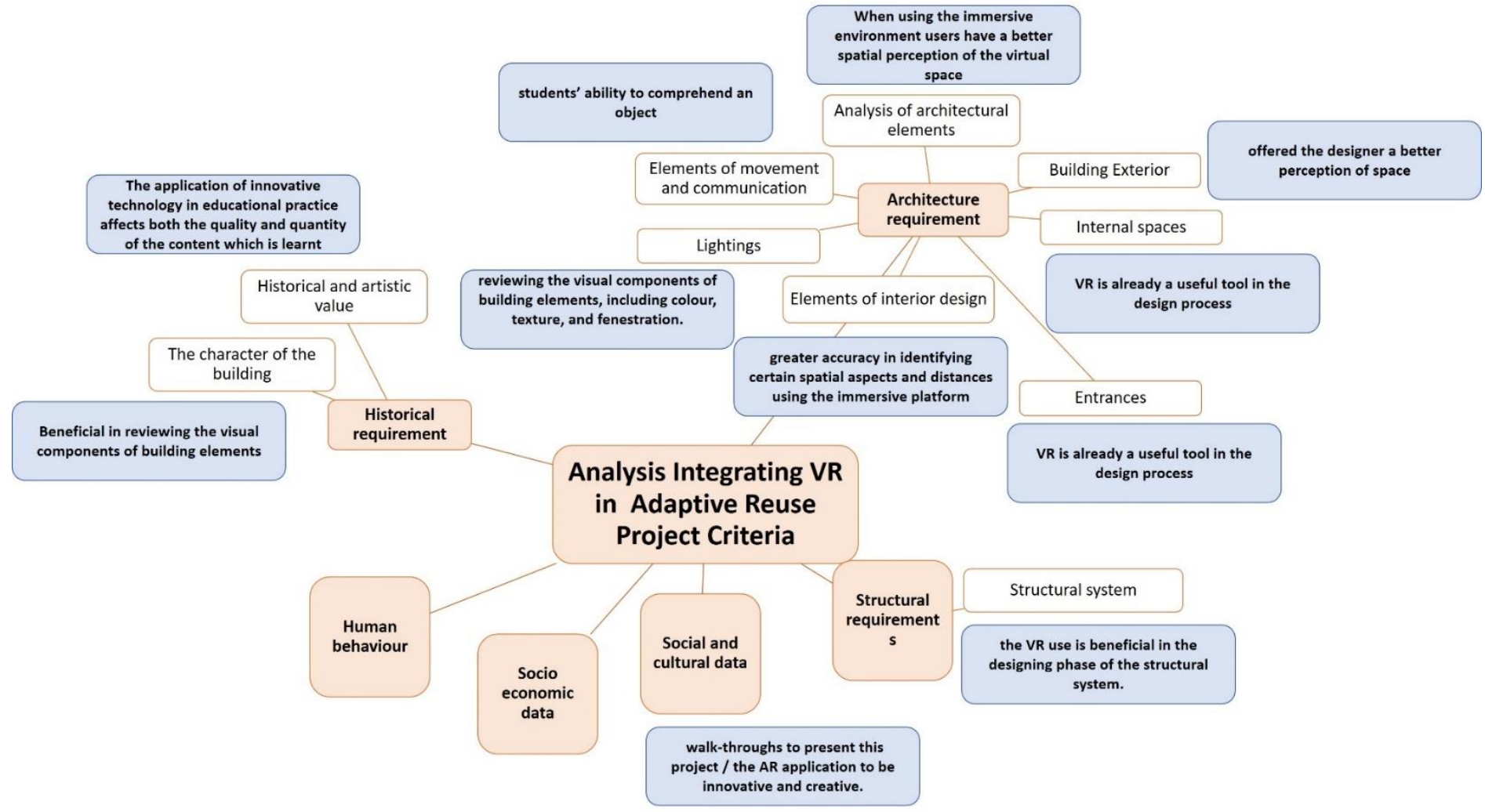

Figure 5 Integration of virtual reality in adaptive reuse design process, source: researcher

\section{Conclusion}

This research discuss the adaptive reuse design process and the need for updating the methods used in the redesign of historical building as each design case should be conducted while following the adaptive reuse correct process so its architecture and significant character is not erased and forgotten, so in this research the analytical, comparing and deductive approaches where taken in reviewing the principles and requirements of adaptive reuse process and determine the architect role in the redesign of the building, then analysing 
international and national case studies to determine the design process steps that can be aided using Virtual reality technology to ensure the design to be successful.

After analysing and researching how the virtual reality technology can be integrated in the design process, the proposal of the research was the integration of adaptive reuse process with virtual reality to meet successful needed adaptive reuse requirements.

\section{ACKNOWLEDGMENT}

I would like to express my appreciation to everyone helped in accomplishing the work, all my gratitude for your guidance and valuable support.

\section{REFERENCES}

\section{References}

[1] Abdelhameed, W., 2013. Virtual reality use in design studios: a case of studying structure and construction. Procedia computer science, Volume 25, pp. 220-230.

[2] Campbell, D. B., 2021. A Critique of Virtual Reality in Architectural Design Process. Hit.washington, Volume 94-3.

[3] Damla Misirlisova, K. G., 2016. Adaptive reuse Strategies for heritage buildings: A holistic approach. Sustainable Cities and Socity, Volume 26, pp. 91-98.

[4] Dorta, T. \& Lalande, P., n.d. The Impact of virtual reality on the design process, Do computers make a difference?. ACADIA Conference Proceedings, Issue 22-25, pp. 138-163.

[5] Farrag, N., 2018. The viability of adaptive reuse of historical buildings as schools in Egypt. National Research Center, 7(20774435), pp. 337-343.

[6] Frontera, E. B., 2020. Teaching Students to build historical buildings in virtual reality: a diadactic strategy for learning history of art in secondary education. themes in science and technology education, Issue Special Issue, pp. 165-184.

[7] Gewirtzman, F., 2016. Adaptive Reuse Architecture Documentation and Analysis. J Archit Eng Tech, 10(4172/2168), p. 172.

[8] Korumaz, M., 2017. The Adaptive Reuse of Kirkuk Citadel. Iconarp International J. of Architecture and Planning, 30(10.15320), pp. 117-139.

[9] Lee, J. G., 2020. End - User Augmented Relaity Utilization for Architectural Design Review. Appl. Sci mdpi, Volume 10, pp. 53-63.

[10] Onvesolu, M. O. \& Eze, F. U., 2011. Understanding Virtual Reality Technology: Advances and Application. Advances in Computer Science and Engineering, 1(1), pp. 127-132.

[11] Paesa, D., Eduardo, A. \& Javier , I., 2017. Immersive environmant improving the understanding of architectureal 3D models: comparing user spatial preception between immersive and traditional virtual reality systems. Automation in Construction, Volume 84, pp. 292-303.

\section{AUTHORS}

First Author - Mahmoud Foud Mahmoud, Professor at Department of architecture, design, and urban planning, Suez Canal University, Ismailia, Egypt

Second Author - Ahmed Saleh Khedr, Professor at Department of architecture, design, and urban planning, Suez Canal University, Ismailia, Egypt.

Third Author - Fayrouz Ashraf Abd El-Rahman, Demonstrator in Architecture Department, Suez Canal University, Ismailia, Egypt.

Correspondence Author - Fayrouz Ashraf Abd El-Rahman, fayrouzashraf1131996@gmail.com, fayroz.ashraf@eng.suez.edu.eg . 